\title{
The use of psychotropic medications and non-pharmacological approaches in everyday life: a qualitative study of the lived experience ${ }^{* 1}$
}

\section{$\bigcirc$ uso de medicamentos psicotrópicos e abordagens não farmacológicas na vida cotidiana: um estudo qualitativo da experiência vivida}

\author{
Agnes Fonseca Ribeiro Filardi*2 \\ Simone de Araújo Medina Mendonça*3 \\ Dienane Ramalho-de-Oliveira*4
}

Increased consumption of psychotropic drugs has been noted in Brazil and other Western countries in the last few decades for different reasons. The objective of this study was to understand the lived experience of individuals who used psychotropic drugs to cope with the problems faced in daily life. A qualitative study guided by hermeneutic phenomenology was carried out. In-depth interviews were conducted. The experience was grouped into two

*1 The results come from the thesis that has been in development since 2015 - $\mathrm{O}$ uso dos medicamentos psicotrópicos e abordagens não farmacológicas no tratamento de problemas psicossociais — saúde mental e bem estar — in the Program in Medicines and Pharmaceutical Assistance. Faculty of Pharmacy, Federal University of Minas Gerais.

This study was approved by the Research Ethics Committee of the Federal University of Minas Gerais (COEP/UFMG) (CAAE: 30244714.9.0000.5149). *2,3,4 Universidade Federal de Minas Gerais - UFMG (Belo Horizonte, MG, Brasil). 
themes: experience of using psychotropic and the search for non-pharmacological approaches. Psychotropics were considered necessary for regaining a point of equilibrium when the problems faced were recognized as having a high degree of difficulty. In some cases, the drugs were perceived as insufficient for solving the problem, leading or not to the search for alternatives to deal with the difficulty.

Key words: Hermeneutics, qualitative research, psychotropic drugs, life change events

\section{Introduction}

In the last few decades, increased consumption of psychotropic drugs has been noted in various countries (Jureidini \& Tonkin, 2006; Liebrenz et al., 2015; MacDonald et al., 2009; Sabahi, Sepehri, Mohsenbeigi \& Sepehrie, 2014; Stuart et al., 2017). In Brazil, a study on the frequency of use of benzodiazepine anxiolytics found an increase in consumption in the country's 27 state capitals. The highest percentage of consumption was in the capitals from the Southeast region and the lowest was in the capitals from the North region (Azevedo et al., 2016). The results of Brazilian studies demonstrate that consumption in the country is significantly associated with women, elderly people and greater utilization of health services (Costa, Ceccato, Melo, Acurcio \& Guimarães, 2017; Schallemberger \& Colet, 2016; Silva, Botti, Oliveira \& Guimarães, 2015). On the other hand, a study conducted in two cities from the State of Goiás, with members of the Military Police $(n=221)$, in which most of the participants were men (94.6\%), indicated a prevalence of $6.8 \%$ for the use of sedatives, anxiolytics and antidepressants throughout life (Costa et al., 2010).

The literature has shown that the use of these drugs extends beyond the recommendations of clinical protocols and therapeutic guidelines (Fleck et al., 2009; Griffin, Kaye A.M., Bueno \& Kaye A.D., 2013). Benzodiazepines (BZD) have been used chronically, despite being more effective when used on a short-term basis (Liebrenz et al., 2015; Manthey et al., 2011; Naloto et al., 2016; Silva et al., 2015; Souza, Opaleye \& Noto, 2013). Selective serotonin reuptake inhibitors (SSRI), recognized as safe and tolerated well by most patients, do not always meet all the criteria necessary for use as antidepressants. They are used 


\section{SAÚDE MENTAL}

for long periods and their indication is perceived as a good option among existing alternatives for dealing with problems manifested by patients (Harris et al., 2011; Jureidini \&Tonkin, 2006; MacDonald et al., 2009; Olfson, Steven \& Marcus, 2009).

Psychotropic drugs have been used in various countries, whereas non-pharmacological therapies have received little attention. In this context, the use of these medications is prevalent for dealing with human suffering and has eclipsed the use of other approaches (Anthierens et al., 2010; D'Incau, Barbui, Tubini \& Conforti, 2011; Mercier et al., 2013; Ryan, Rapley \& Dziurawiec, 2014). There is a need for more studies to assess and understand the use of psychotropic drugs and explore the use of non-pharmacological approaches.

It is especially important to understand, within the Brazilian context, the meanings assigned by patients to psychotropic drugs for regaining equilibrium or overcoming emotional difficulties. In addition, the expectations and conditions where drugs are viewed as necessary, as well as their effects and the reasons for continuing or stopping their use, need to be better understood. Therefore, the objective of this study was to understand the lived experience of individuals using psychotropic drugs to regain emotional balance or overcome personal difficulties that generate stress, tension, irritation, anxiety, fear, sadness or any other type of malaise.

\section{Method}

\section{Study design}

This qualitative study used the philosophical assumptions of hermeneutic phenomenology proposed by Heidegger and phenomenology of practice as presented by Max van Manen. Heidegger's philosophy is directed towards human existence, unlike his predecessor Husserl who focused in the understanding of human consciousness always in relation to an object. In Heidegger's view, the world is a set of geographical, historical, social and economic conditions in which each person is immersed. The philosopher replaces Husserl's concept of intentionality of consciousness with the concept of Daisen, or being there. This term in colloquial German means the daily existence of human beings, referring to a way of being that is characteristic of all people or a specific person. Therefore, Daisen refers to the way in which human beings exist, act and are involved in the world (Casanova, 
2013; Dreyfus, 1991; Heidegger, 1991, 2012; van Manen, 1990, 2014). The focus of a study, guided by Heideggerian precepts, is not in relation to the pure content of human subjectivity, but involves the implications of the narratives of human beings in the world of lived experience (Converse, 2012). A Heideggerian approach presupposes that studies are always interpretative, revealing that which was previously hidden, and the assumptions that researchers bring to the research experience are examined instead of suspended. On the other hand, the qualitative phenomenological research proposed by van Manen is a specific project for the understanding of human experience, rooted in professional practices such as pedagogy, psychology, education, and healthcare. The fundamental model of this approach is a textual reflection on the lived experience and practical daily activities. The method makes it possible to elucidate the world of life, allowing phenomena to speak for themselves, referring the theory and practice of interpretation to the meaning of the phenomenon described, which takes into account how the person lives and interprets the "text of life". The method seeks to understand and interpret the invariant structure of the lived experience (van Manen, 1990, 2014; Adams \& van Manen, 2017; Ho, Chiang \& Leung, 2017).

This study was approved by the Research Ethics Committee of the Federal University of Minas Gerais (COEP/UFMG) (CAAE: 30244714.9.0000.5149). The study was written using the consolidated criteria for qualitative research reports (Tong, Sainsbury \& Craig, 2007).

\section{Participants}

For the recruitment of participants, pamphlets with a brief description of the study were distributed in multiple public places - universities, drugstores, ambulatory clinics, and public buildings, in the city of Belo Horizonte, Minas Gerais, Brazil. The pamphlet invited people that had experiences taking psychotropic medications to cope with the difficulties of their personal lives, such as stress, tension, irritation, anxiety, fear, or sadness. It also had the name of the principal investigator with a phone number and an email address. Those who contacted the researcher said they identified with the research call and reported using psychotropics to overcome certain difficulties faced in life.

The participants in the study were men and women from the general population, of varying ages and levels of education, who experienced the phenomenon being studied, i.e., used psychotropic drugs to cope with daily 


\section{SAÚDE MENTAL}

life problems. The participants were informed of the study's objective, which was reflected in the situations they had lived, i.e., all those included said they had started using psychotropic drugs to cope with feelings unleashed by a specific problem in their daily lives (work, family, romantic relationship, marriage or educational training). The researchers were mainly interested in interviewing people who were using benzodiazepines or antidepressants. The participants chose the location of their preference for the interview, and, at the time of the interview, they signed a free and informed consent form and were informed that they were free not to answer questions or stop the interview whenever they desired. All the authors are experienced researchers carrying out studies on multiple aspects of patient-centered care, including the lived experience of using medications.

\section{Interviews}

The data were collected through the in-depth interview technique, recognized as a legitimate way to collect qualitative data because it enables exploring the experiences of participants and makes it possible to grasp and understand social behaviors. Hermeneutic phenomenological research seeks to shed light on the lived experience and reveal the connection between the subject and the phenomenon studied (Minayo, 2014; Poupart et al., 2014). In-depth interviews addressed the experience of participants with psychotropic use, how they experienced starting the medication, the benefits or challenges they perceived in the beginning, the duration of the treatment, the experiences associated with the maintenance or cessation of use, the use of other approaches to the solution of the problem and finally the meaning of the medication in their daily lives. The interviews were conducted until data saturation was reached, in other words, the sample was qualitatively established as sufficient in the researchers' evaluation because started to present redundancy (Sandelowski, 1995; Bauer, \& Gaskell, 2018). To ensure credibility, the interviews were recorded and transcribed verbatim by the first author.

\section{Analytic Procedure: Thematic Analysis}

The data were treated determining the themes corresponding to the structure of the phenomenon. The researchers maintained an open posture to 
the world of the phenomenon, examining it without imposing their theories or hypotheses. The focus was on the orientation, description, and interpretation of the invariant structure, the underlying central meaning of the lived experience (van Manen, 1990, 2014).

A holistic approach was used for the thematic analysis, corresponding to the first stage of the data treatment. The researcher (first author), during the transcription of the data, and after reading and rereading the interviews numerous times, became familiar with the meaning that permeated all the narratives, enabling her to capture the overall meaning in relation to the text as a whole. At that time, the theme - the fundamental or main meaning of the text as a whole - was represented by a phrase (van Manen, 1990).

In the second stage, the analysis process was broken down, establishing subthemes or subdivisions contained in the overall understanding. In this process, a selective or line-by-line approach was used, which involved a thorough reading, looking for phrases, sentences or statements that added meaning or revealed the lived experience. The co-authors separately performed the same analysis process as the first author and the themes and subthemes that emerged were discussed until consensus was reached. The 864 theme is the experience in question, the meaning, the key point and the way through which the phenomenon is captured, revealing its structure, without which the lived experience would not exist (van Manen, 1990).

Data processing occurred after the interviews were uploaded to the NVIVO ${ }^{\circledR}$ software (Version 11). To help with the organization and analysis of the data, the software was used, a tool which enabled the text to be read systematically, cut out, organized hierarchically and coded into "nodes" that are portions of the text equivalent to themes and subthemes.

No data that would enable the identification of the participants was included in the results report, in order to ensure privacy, confidentiality, and anonymity. In the data presentation, fictitious names were assigned to the participants.

\section{Results}

\section{Characteristics of the participants and psychotropic drug use}

The interviews were conducted from September 2014 to June 2015 with 19 people — 14 women and 5 men — with a minimum age of 


\section{SAÚDE MENTAL}

18 and a maximum of 81 years, who reported using psy-chotropic drugs to overcome problems faced in their lives. The maximum time of interview was 1 hour 20 minutes and 33 seconds, minimum 14 minutes and 7 seconds, and the mean time was 47 minutes and 34 seconds. The first author was responsible for the transcription of the audios. Table 1 shows the participants' characteristics.

TABLE 1

Characteristics of the participants

\begin{tabular}{|cccc|}
\hline PARTCIPANTS & AGE & $\begin{array}{c}\text { EDUCATION } \\
\text { WOMEN }\end{array}$ & OCCUPATION \\
Natalia & 81 & High School & Seamstress \\
Madalena & 55 & High School & Cleaning services \\
Andreia & 54 & High School & Housewife \\
Elisangela & 52 & High School & Manicure \\
Jaqueline & 49 & Higher Education & Teacher, Public School \\
Sofia & 47 & Higher Education & Public Servant \\
Rafaela & 47 & Higher Education & Teacher, Public School \\
Tábata & 38 & Higher Education & Teacher, Public School \\
Beatriz & 33 & Higher Education & Public Servant \\
Laura & 27 & Technical Course & Information technology Technician \\
Elis & 27 & Higher Education & Humanities Professional \\
Tânia & 25 & Higher Education & Healthcare Professional \\
Denise & 24 & Undergraduate & Pharmacy Student \\
Ana & 18 & Undergraduate & Psychology Student \\
& & MENS & \\
Murilo & 65 & Higher Education & Public Servant \\
Victor & 59 & High School & Administrator, Public School \\
Walter & 42 & Higher Education & Public Servant \\
Diego & 40 & Technical Course & Information Technology Technician \\
Valdomiro & 32 & High School & Vigilant \\
\hline
\end{tabular}

Among all the participants, a total of 32 psychotropic drugs were used: SSRI accounted for $35 \%$, benzodiazepines for $28 \%$, tricyclic antidepressants for $16 \%$, selective dopamine and norepinephrine reuptake inhibitors $6 \%$, mood stabilizers $6 \%$, norepinephrine-dopamine reuptake inhibitors $3 \%$, tricyclic antidepressants $3 \%$ and anticonvulsants $3 \%$. 
The maximum age of the women participants was 81 years, the minimum age was 18 years and the mean age was 41 years. The maximum drug use time was 38 years, the minimum time was one year and the mean time was nine years.

There were five men who participated in the interviews, with maximum and minimum age of 65 years and 32 years, respectively, and a mean age of 48 years. The maximum drug use time was 27 years, the minimum time was one year and the mean time was 13 years.

Problems faced in daily life were the determining factors for starting to take psychotropic drugs, which, over the course of time, continued for the same reasons that led to their start or due to new problems such as insomnia, adverse effects from stopping the use of the primary medication (reported primarily by SSRI users) and dependency in the case of BZD users. Diego and Elis said they did not like needing the drugs and stopped using them, representing a minority of users. Elisângela stopped using fluoxetine after she started attending a church. Ana also did not like the drugs, but felt it was necessary to use them for the time being, and said she did not intend to use them chronically. Denise and Tânia planned to stop soon after they started taking them. Bianca stopped using clonazepam because her physician contraindicated it, and she started using citalopram. Jaqueline, who planned to retire in five years, said she intended to use the drug for two more years in order to cope with her work environment. For the final three years, she still did not know what she would do to deal with her daily stress. Valdomiro tried stopping, but when the symptoms of anxiety returned, he spoke with his doctor and went back on using the drug. Rafaela, despite "loving the drugs", tried stopping several times, either on her own or with medical supervision, but could not stand the side-effects of stopping them, even when use was gradually reduced. Walter said he was not being monitored by a physician but intended to schedule an appointment to renew the prescription. Tábata started the drugs a short while ago. Andréia, Madalena, Murilo, Natalia, Rafaela, Sofia, Walter, Valdomiro and Victor did not have any intention to stop using psychotropic drugs. Laura was doing well but was going to keep using the drug to help her concentrate on her studies. The reasons for using psychotropic drugs are presented in Table 2. 


\section{SAÚDE MENTAL}

TABLE 2

Reasons for starting and continuing to use psychotropic drugs

\begin{tabular}{|c|c|}
\hline $\begin{array}{c}\text { Reasons for starting to use } \\
\text { psychotropic drugs }\end{array}$ & $\begin{array}{c}\text { Reasons for continuing to } \\
\text { use psychotropic drugs }\end{array}$ \\
\hline Work & Work \\
Family & Marriage \\
Romantic Relationship & University \\
Marriage & Studies \\
Separation & Side-effects of quitting use \\
University studies & Insomnia \\
& Dependency \\
\hline
\end{tabular}

\section{Lived experience with psychotropic drug use}

The experience under investigation was grouped into two main themes: the first — "I wanted the feeling to go away" — is related to the experience of anguish and loss of control that leads to starting and maintaining the use of a psychotropic drug. This theme has the following five subthemes: Searching for help; The good and the bad; Most liked them, some liked them a lot, not many disliked them, and others were dependent; "The drugs are a crutch for me now": stopping or continuing taking psychotropic drugs; and the reasons that led to maintaining or stopping use. The second theme - "Understanding my reactions, emotions, and body" - deals with the search or not for non-pharmacological approaches. The subthemes are psychotherapy, physical activities, acupuncture, and faith. The themes and subthemes are presented in Table 3. 
$\begin{array}{lllllll}R & E & V & \text { I } & S & T & A\end{array}$

LATINOAMERICANA

DE PSICOPATOLOGIA

F U D A M E T A L

TABLE 3

Presentation of the themes and subthemes

\begin{tabular}{|} 
Theme 1: "I wanted the feeling to go away" \\
Searching for help (prescription) \\
The good and the bad \\
Most liked them, some liked them a lot, not many disliked them, and others were dependent \\
"The drugs are a crutch for me now": stopping or continuing taking psychotropic drugs \\
Limitations of the psychotropic drug for solving the problem
\end{tabular}

\section{Theme 1: "I wanted the feeling to go away"}

Problems faced in daily life triggered feelings of anger, anxiety, stress, sadness or anguish in the participants. The suffering endured was reported as very strong. The perception, when experiencing these emotions, was that their lives were out of control. People feared not being able to manage the situation and not being considered a normal person. Their desire was not to suffer. It was at this moment that the lived experience with psychotropic drugs commenced, when the drugs were used for coping with the suffering caused by the difficulties lived.

Subtheme 1.1: Searching for help

Help was usually requested from physicians and psychotropic drugs were prescribed and used as a solution for coping with, overcoming or enduring participants' life problems. Interestingly, patients often judged the competence of a doctor by a prescription order, as well stated by the following individual:

Everyone knows - in fact, there's a certain mindset - that when you go to the doctor, if you don't leave with a prescription, that's not a good doctor. (Tânia).

Subtheme 1.2: The good and the bad

For the participants in this study, psychotropic drugs control feelings of anguish, sadness, and anger, as well as emergency situations or spikes 


\section{SAÚDE MENTAL}

of feelings, which are emotional reactions triggered by problems. They described the benefits of the drugs when they first started using them, which distanced them from the problems they were experiencing. As a result of the drugs, individuals felt more peaceful, withstood pressure and social stress more easily and were less affected by the difficulties they were facing. The following narratives exemplify these experiences:

What I'm hoping for is that the pain, sadness, anguish, and anxiety will end. To be stable, feel at peace, have tranquility. (Beatriz)

Every time I took clonazepam I was seeking that sensation of feeling nothing. Citalopram controls the anxiety on a daily basis, so I don't have anxiety anymore. So, when something happens, I feel that I don't have those same emotional highs and lows, you know, which led me to start taking clonazepam. (Beatriz).

[...] it only brought good things, I was able to calm down, feel better, accept myself, and see the world in a way I wasn't able to see when I was dealing with that problem (Denise).

However, the effects of psychotropic drugs were not only positive. Participants also reported adverse effects such as a hangover sensation, feeling thirstier and hungrier, headaches, lower sex drive, dizziness, nausea, grogginess and drowsiness, drop in blood pressure, slower thought processes and memory loss.

It was like I was sleeping all day and this bothered me a lot (Diogo).

Clonazepam knocks you out. It makes you totally sleepy and you often can't do anything (Elis).

Subtheme 1.3: Most liked them, some liked them a lot, not many disliked them, and others were dependent

Regarding participants' feelings toward psychotropic drugs, some interviewees reported liking them a lot and others did not like them. Those that liked the drugs, liked them almost unconditionally, whereas those who did not like them (the minority), detested them. Although the mean time of psychotropic drug use was high, not all of the participants liked them; in this case, some had used the drugs for a shorter period of time, against their will. The interviewees' narratives yielded examples of the relationship that each one established with the psychotropic drug: Beatriz and Rafaela liked them a lot, Diego made it clear he did not like them at all, and Murilo and Victor talked about their dependence.

Clonazepam is like putting out a fire, a bucket of water on a fire. It's very good! (Laughs) Clonazepam is very good! (Beatriz). 
Ah, alprazolam, it's so nice! I'm a faithful customer of this laboratory, my preferred supplier (Rafaela).

From what I can see, maybe it's different in other families (laughs), but in my family it doesn't work. It doesn't solve people's problems, and even made them worse and added a few more (Diego).

I'm dependent on alprazolam for the tranquility it gives (Murilo).

Clonazepam is for sleeping, but it gives you, how do you say it... You get dependent

on it, don't you? (Victor)

Subtheme 1.4: "The drugs are a crutch for me now": stopping or continuing taking psychotropic drugs

It can be observed in the participants' narratives that the reasons for starting to use a psychotropic drug are not always the same as those for continuing to use it. New problems arise and reinforce the need to continue using the drug to cope with daily stress. The idea of stopping to use the drugs comes up in the interviews, but only a minority actually do stop. Most had been using them for a long period of time. Mood stability, sedation, habit, fear, dependence, and the effects of stopping were reasons to continue using them.

I go on taking them. I'm also afraid to stop (Andreia).

I don't think I can stop. The same with clonazepam, even if I sleep little, I need clonazepam (Victor).

So, the drugs are a crutch for me now. Like that thing with women, I'll go out naked, but not without lipstick. I'd go out naked, but I won't go out without the drug in my purse. (Rafaela).

I already tried five times, even under medical supervision, to stop taking sertraline. It didn't work (Rafaela).

In the case of Denise and Laura, they said they were doing well. They told their doctors they wanted to stop using their drugs, but were encouraged to continue using them to cope with their many daily tasks.

I've got a thousand things going on during the week and on the weekend. So, he said: "You shouldn't stop taking them now, first study and once you've graduated, you can get off them." (Denise).

I'm doing very well right now. I know they were good for me, that I needed them, but when I went to the doctor to start getting off them, he agreed but said he would not take me off them quickly. He was going to leave the prescription at $20 \mathrm{mg}$, which is the minimum, at least until I was hired in a job selection exam or was stable in another job (Laura). 


\section{Theme 2: "Understanding my reactions, emotions, and body": the limitations of psychotropic drugs to solve individuals' problems}

The participants were categorical that the problems they faced were serious enough that they would be unable to cope with the situation without medications. They also stated that the psychotropic drugs helped them mainly in the beginning, since they had a calming effect and distanced them from the problem. In their accounts, the participants referred to the limitations of pharmacological treatments - in terms of actually solving the problem - since psychotropic drugs are effective for soothing emotions, but the underlying reality remains the same.

It blocked things out, but didn't resolve the situation. The drug doesn't have the power to work out situations, does it? But what I was trying to resolve was my reaction to the situation. And clonazepam does this, which is great (Beatriz).

You have to take into consideration the two factors - the psychological and the biological. But my impression is that taking the drug won't make me better. However, at the same time, I also think you can't reject the biological side, because people are bio-psycho-spiritual and cultural beings. So, you have to take it all into account (Ana).

Another participant added:

Many times, even when you're facing a more serious problem, there's no professional who actually listens to you, to intermediate with the drug. Like that, you can end up taking antidepressants your whole life (Elis).

It is interesting to stress that, according to the participants, non-pharmacological approaches had a different effect than the psychotropic drugs and were recognized as being positive and important both by those who sought this non-pharmacological option and those who did not.

\section{faith \\ Subtheme 2.1: Psychotherapy, physical activities, acupuncture, and}

In this study, non-pharmacological approaches to deal with life stressors were on a secondary plane, and psychotherapies were used by half of the interviewees, for shorter periods of time and less frequently. In relation to physical activities, the frequency was even lower. A minority reported exercising; most did not like exercising and claimed not having time for it. Kung $\mathrm{Fu}$, described as an effective way to improve emotional difficulties, 
was practiced by Ana, the youngest of all participants. Acupuncture was mentioned by Tânia as an excellent method for relieving headaches caused by daily stress, but she also reported not having time to attend the sessions. The following excerpts from Diego, Beatriz, Elis, Ana and Tânia illustrate their experience with non-pharmacological treatments, such as psychotherapy, Kung $\mathrm{Fu}$ and acupuncture.

And I talked, talked, talked there... At a certain moment, I discovered that I was, in fact, doing a lot of things in my professional life, in relation to my family and all, which were bothering me (Diego).

It helped me a lot to understand my reactions to things; it kind of took the place of... Understanding my reaction took the place of clonazepam (Beatriz).

[...] through therapy I was getting it together, finding other ways to try and calm myself, to think about other things. Therapy gave me self-control and has helped me to depend less on drugs (Elis).

I was always very anxious, so I began playing a sport and that started to help me. It's really helping me a lot! I keep on doing it. I won't stop. It's helping me a lot! (Ana)

I remember one day when I went... I couldn't stand the headache, but it seems like there's a point here in the head... And I left walking on clouds. It had a stronger effect than a powerful analgesic (laughs) (Tânia).

\section{Discussion}

In addition to the increased consumption of psychotropic drugs, there is also a process of medicalization. For Peter Conrad (1992; 2007), medicalization is not a neutral term that describes only something that has become a medical problem, but rather a critique that makes it possible to contextualize the overuse of medicines as a process in which certain behavior and /or a non-medical problem is defined as a disease, disorder or medical problem; and authorization is given to the medical profession to offer individuals some type of treatment (Conrad, 1992; 2007). Populations are culturally transformed through the practice of medicalization and this dynamic affects the ability to cope with the inevitable adversities of life (Tesser, 2006). The results of this study showed the therapeutic pluralism of psychotropics, especially as the predominant strategy to overcome the problems faced in daily life. 


\section{SAÚDE MENTAL}

With respect to the first theme "I wanted the feeling to go away", the participants reported that the difficulties they experienced in life exacerbated their feelings, which caused them, at a specific moment, to realize they needed help. On the one hand, the intensity of the emotions made them think they were losing control of their lives, which provoked an underlying fear of going crazy or not being normal. On the other hand, psychotropic drugs provided relief because the feelings of anxiety, anguish, sadness, agitation, anger and stress were no longer present. In the beginning, the drug had a calming effect, which enabled the participants to no longer be "affected" by the problem. This distancing was considered important so that they could better grasp or understand what was actually happening to them. By using the psychotropic drugs, their emotions were brought under control and they could "look at", "discern" or experience the problem without being affected by it. The exacerbated emotional feelings were considered a threat to normality, but through the use of psychotropic drugs it was possible to live a normal life, even if circumstances involving the family, workplace, romantic relationships or studies were not the most favorable.

From the perspective of the study participants, the benefit of the drugs was primarily when they first started using them, since they distanced them from the difficulties they were experiencing. The results of a qualitative study with 32 patients who used psychotropic drugs also demonstrated that the drugs were perceived as being useful especially in the initial stage, referred to as the reconnection stage in the study (Kartalova-O'Doherty \& Doherty, 2010).

In relation to the subthemes in the present study, the continued use of psychotropic drugs, over time, started being associated by the participants with other difficulties in their lives, primarily insomnia, dependence, and sideeffects when trying to get off them. Other studies showed similar results. A qualitative study developed by Liebrenz et al. (2015) highlighted social stress as one of the main reasons for the initiation and maintenance of high-dose benzodiazepines (Liebrenz et al., 2015). Another study mentioned the same reasons patients continue using BZD such as fear of not being able to sleep and recurrence of the symptoms, as well as insufficient reasons for stopping (Souza et al., 2013).

In regard to staying on SSRI, patients often wanted to stop using them, but were unable to, due to the number of side-effects they experienced (Verbeek-Heida \& Mathot, 2006). In contrast, a minority of the patients in the present study stopped using them - Diego and Elis, who did not like 
the drugs and Elisângela, who no longer felt the need to continue using them after she started going to a church. In this case, a personal decision was the determining factor for discontinuing the drug. Most participants in this study used psychotropic drugs for long periods of time, apparently presenting no adherence problems. The results of van Geffen et al. (2011) showed that "the discontinuers more often seemed to have a more negative attitude toward SSRI therapy than the continuers" (van Geffen et al., 2011). On the other hand, Ferreira et al. (2017) argued that poor adherence to the use of psychotropic drugs is a challenge in the treatment of mental disorders mainly related to the exacerbation of adverse effects.

The second theme "Understanding my reactions, emotions, and body" involved searching (or not) for non-pharmacological strategies to overcome the difficulties experienced. In the present study, most of the participants reported resisting the use of non-pharmacological approaches to overcome their problems. In this respect, participants of another qualitative study stated that prescribed drugs were important but other approaches were also necessary to achieve wellness (Werremeyer, Skoy \& Kelly, 2017).

A study found that $97 \%$ of the physicians recognized that most of their 874 patients who used BZD could resort to non-pharmacological approaches for managing stress, anxiety, and insomnia, but there were obstacles to this treatment proposal on the part of physicians, patients and the healthcare system. As for the indication of non-pharmacological approaches, one-third of the physicians said that these alternatives should follow the use of medications. Approximately half of them considered the non-pharmacological alternatives as something that took a lot of time and was costly, and that patients resisted adherence. Some professionals perceived that patients felt they were not being taken seriously if they did not receive a prescription in a consultation (Anthierens et al., 2010).

On the other hand, a systematic review was carried out to assess the efficacy and cost of counseling for patients with mental and psychosocial problems in primary care. The main findings were that clinical efficacy was significantly higher in the group that received counseling as opposed to normal care, in terms of short-term mental health results. Levels of satisfaction with counseling were high and its overall cost was similar to regular care (Bower, Knowles, Coventry \& Rowland, 2011).

In relation to physical activities, a minority of the participants in this study exercised or engaged in any type of sports, even though some interviewees acknowledged their benefits. In contrast, recent studies 


\section{SAÚDE MENTAL}

demonstrated the positive effects associated with physical activity, such as enhanced well-being and lower stress levels (Coelho et al., 2017; Verani, Souza, Parcias, Matias \& Guimarães, 2016).

The results are consistent with the findings of other research and it was clear that psychotropic medications had been used to overcome the difficulties faced in everyday life. It should be stressed that this research, as a qualitative study, does not intend to generalize its findings, but to invite the reader for a critical reflection on the phenomenon of medicalization that is currently going on in our societies. The authors do not claim that the study is representative for all the users of psychotropic drugs. In addition, future research should investigate the effectiveness of non-pharmacological approaches and coping strategies for daily life stressors.

\section{Conclusion}

A qualitative hermeneutic phenomenological research approach guided the researchers to suspend their assumptions and current dogmas while conducting the investigation of the phenomenon examined. This approach enabled the researchers to adopt an attitude of openness so the dimensions of the lived experience of the phenomenon studied would emerge. In this sense, it was found that using psychotropic drugs provided an important assistance for individuals to initially deal with problems of an emotional nature, since the drug had a calming effect and permitted a certain distancing from the problem. On the other hand, the psychotropic drugs were used for long periods of time and only a minority was able to stop using them. Prolonged use of psychotropic drugs occurred even though the participants were aware of the limits of using them for a definitive solution to the problems they were experiencing. They also acknowledged the importance of non-pharmacological approaches for overcoming their difficulties.

The increasingly common practice of using psychotropic drugs for various purposes, in addition to the naturalization of their use, reinforces pharmacological solutions as a way of coping with the emotions unleashed by different problems. Medications, as healing agents, are often used without taking into account the circumstances that involve human beings in the world and other perspectives for solving the problem. Non-pharmacological approaches should also be considered as effective alternatives for overcoming life difficulties. Daily life stressors and coping strategies 
Acknowledgments: We sincerely thank everyone who participated in this study.

\section{References}

Adams, C., Manen, \& M. A. V. (2017). Teaching Phenomenological Research and Writing. Qualitative Health Research, 27(6), 780-791. doi: 10.1177/1049732317698960.

Anthierens, S., Pateels, I., Habraken, H., Steinberg, P., Declercq, T., \& Christiaens, T. (2010). Barriers to non-pharmacologic treatments for stress, anxiety, and insomnia: family physicians' attitudes toward benzodiazepine prescribing. Can Fam Physician, 56(11), 398-406. doi:10.5750/ejpch. v6i2.1442.

Azevedo, A. J. P., Araújo, A. A., \& Ferreira, M. A. F. (2016). Consumo de ansiolíticos benzodiazepínicos: uma correlação entre dados do SNGPC e indicadores sociodemográficos nas capitais brasileiras. Ciência \& Saúde Coletiva, 21(1), 83-90. doi.org/10.1590/1413-81232015211.15532014.

Bauer, M.W., \& Gaskell, G. (2018). Pesquisa qualitativa com texto, imagem e som; um manual prático (13 ${ }^{\mathrm{a}}$ ed.). Petrópolis, RJ: Vozes.

Bower, P., Knowles, S., Coventry, P. A., \& Rowland, N. (2011). Counselling for mental health and psychosocial problems in primary care. (Review), Cochrane Database Syst Rev, 9, 1-75. doi: 10.1002/14651858.CD001025.pub3.

Casanova, M. A. (2013). Compreender Heidegger. Petrópolis, RJ: Vozes.

Coelho, I. P. S. M., Formiga, L. M. F., Machado, A. L. G., Araújo A.K.S.,.Mendes, T.F., \& Borges, F.M. (2017). Prática de atividade física na terceira idade. Rev Fund Care Online, 9(4), 1107-1112. doi: 10.5205/reuol.10827-96111-1ED.1106201721

Conrad, P. (1992). Medicalization and social control. Annu. Rev. Sociol., 18, 209-32. doi:18.080192.001233.

Conrad, P. (2007). The Medicalization of Society: On the Transformation of Human Conditions into Treatable Disorders. Baltimore: Johns Hopkins University Press.

Converse, M. (2012). Philosophy of phenomenology; how understanding aids research. Nurse Researcher, 20(1), 28-32. doi:10.7748/nr2012.09.20.1.28.c9305.

Costa, J. O., Ceccato, M. G. B., Melo, A. P. S. Acurcio, F. A., \& Guimarães, M. D. C. (2017). Gender differences and psychotropic polypharmacy in psychiatric patients in Brazil: a cross-sectional analysis of the PESSOAS Project. Cad Saúde Pública, 33(4), 1-13. doi: 10.1590/0102-311X00168915. 


\section{SAÚDE MENTAL}

Costa, S. H. N., Cunha, L. C., Yonamine, M. Pucci, L. L., Oliveira, F. G. F. Souza, C. G. ... \& Leles, C. R. (2010). Survey on the use of psychotropic drugs by twelve military police units in the municipalities of Goiânia and Aparecida de Goiânia, state of Goiás, Brazil. Rev Bras Psiquiatr, 32(4), 389-395. doi.org/10.1590/S151644462010005000023.

D'Incau, P., Barbui, C., Tubini, J., \& Conforti A. (2011). Stressful Life Events and Social Health Factors in Women Using Anxiolytics and Antidepressants: An Italian Observational Study in Community Pharmacies. Gender Medicine, 8(2), 80-92. doi: 10.1016/j.genm.2011.03.003.

Dreyfus, H. L. (1991). Being-in-the-world: A commentary on Heidegger's Being and Time, Division I. Massachusetts, London, England: The MIT Press Cambridge.

Ferreira, A. C. Z., Brusamarello, T., Capistrano, F. C., Marin, M. J. S., \& Maftum, M. A.A. (2017). Vivência do portador de transtorno mental no uso de psicofármacos na perspectiva do pensamento complexo. Texto Contexto Enferm, 26(3): e1000016. doi.org/10.1590/0104-07072017001000016.

Fleck, M. P., Berlim, M. T., Lafer, B., Sougey, E. B., Del Porto, J. A., Brasil, M. A., ... \& Hetem, L. A. (2009). Revisão das diretrizes da Associação Médica Brasileira para o tratamento da depressão (Versão integral). Rev Bras Psiquiatr, 31(Supl I), S7-17, doi.org/10.1590/S1516-44462009000500003.

Griffin, C. E., Kaye, A. M., Bueno, F. R., \& Kaye, A. D. (2013). Benzodiazepine Pharmacology and Central Nervous System-Mediated Effects. The Ochsner J, 13(2), 214-223.

Harris, M. G., Burgess, P. M., Pirkis, J., Siskind, D., Slade, T., \& Whiteford, H. A. (2011). Correlates of antidepressant and anxiolytic, hypnotic or sedative medication use in Australian community sample. Aust N Z J Psychiatry, 45, 249-260. doi: 10.3109/00048674.2010.531459.

Heidegger, M.(1991). Conferências e escritos filosóficos: Coleção os Pensadores, 5. São Paulo, SP: Nova Cultural.

Heidegger, M. (2012). Ser e tempo. Campinas, SP: Editora da Unicamp/Petrópolis, RJ: Vozes.

Ho, K. H. M., Chiang, V. C. L., \& Leung, D. (2017). Hermeneutic phenomenological analysis: the 'possibility' beyond 'actuality' in thematic analysis. Journal of Advanced Nursing, 73(7), 1757-1766. doi: 10.1111/jan.13255. Epub 2017 Feb 17.

Jureidini, J, \& Tonkin, A. (2006). Overuse of antidepressant drugs for the treatment of depression. CNS Drugs, California, 20(8), 623-632. doi: 10.2165/00023210200620080-00002.

Kartalova-O'Doherty, Y., \& Doherty, D. T. (2010). Recovering from mental health problems: Perceived positive and negative effects of medication on reconnecting 
with life. International Journal of Social Psychiatry, 57(6), 610-618. doi: 10.1177/0020764010377396.

Liebrenz, M., Schneider, M., Buadze A, Gehring, M. T., Dube, A., \& Caflisch, C. (2015). High-Dose Benzodiazepine Dependence: A Qualitative Study of Patients' Perceptions on Initiation, Reasons for Use, and Obtainment. PLoS ONE, 10(11), 1-23. doi.org/10.1371/journal.pone.0142057.

MacDonald, S., Morrison, J., Maxwell, M. Munoz-Arroyo, R., Power, A., Smith, M., ... \& Wilson, P. (2009). 'A Coal Face Option'; GPs' Perspectives on the Rise in Antidepressant Prescribing. Br J Gen Pract, 59(566), 299-307.

Manthey, L., van Ven, T Giltay, E. J., Stoop, J. E., Neven, A. K., Penninx, B. W., \& Zitman, F. G. (2011). Correlates of (inappropriate) benzodiazepine use: the Netherlands Study of Depression and Anxiety (NESDA). Br J Clin Pharmacol, 71(2), 263-72. doi: 10.1111/j.1365-2125.2010.03818.x.

Mercier, A., Auger-Aubin, I., Lebeau, J. P., Schuers, M., Boulet, P., Hermil, J. L., \& Peremans, L. (2013). Evidence of prescription of antidepressants for nonpsychiatric conditions in primary care: an analysis of guidelines and systematic reviews. BMC Family Practice, 14(55), 1-10. doi: 10.1186/1471-2296-14-55

Minayo, M. C. S. (2014). O desafio do conhecimento: pesquisa qualitativa em saúde. São Paulo, SP: Hucitec.

Naloto, D. C. C., Lopes, F. C., Filho, S. B., Lopes, L. C. Del Fiol, F. S., \& Bergamaschi, C. C. (2016). Prescription of benzodiazepines for adults and older adults from a mental health clinic Ciência \& Saúde Coletiva, 21(4), 1267-1276. doi.org/10.1590/1413-81232015214.10292015.

Olfson, M., Steven, M. P. H., \& Marcus, C. (2009). National Patterns in Antidepressant Medication Treatment. Arch Gen Psychiatry, Chicago, 66(8), 848-856. doi: 10.1001/archgenpsychiatry.2009.81.

Poupart, J., Deslauriers, J. P., Groulx, L. H., Laperrière, A, Mayer, R., \& Pires, A. P. (2014). A pesquisa qualitativa: enfoques epistemológicos e metodológicos. Petrópolis, RJ: Vozes.

Ryan, Rapley, \& Dziurawiec. The Meaning of Coping for Psychiatric Patients. (2014). Qualitative Health Research, 24(8), 1068-1079. doi. org/10.1177/1049732314541011.

Sabahi, A., Sepehri, G., Mohsenbeigi, \& M., Sepehrie, E. (2014). Patterns of Psychotropic Medication Prescriptions by Psychiatrists for Private Clinic Outpatients in Kerman Province, Iran. Sultan Qaboos University Med J, 14(3), e382-387.

Sandelowski, M. (1995). Sample size in qualitative research. (1995). Research in nursing \& Health, 18, 179-183. doi.org/10.1002/nur.4770180211. 


\section{SAÚDE MENTAL}

Schallemberger, J. B., \& Colet, C. F. (2016). Assessment of dependence and anxiety among benzodiazepine users in a provincial municipality in Rio Grande do Sul, Brazil. Trends Psychiatry Psychother, 38(2), 63-70. doi.org/10.1590/2237-60892015-0041.

Silva, V. P., Botti, N. C. L., Oliveira, V. C., \& Guimarães, E. A. A. (2015). Perfil epidemiológico dos usuários de benzodiazepínicos na atenção primária à saúde. R. Enferm. Cent. O. Min., 5(1), 1393-1400. doi: http://dx.doi.org/10.19175/ recom.v0i0.546.

Souza, A. R. L., Opaleye, E. S., \& Noto, A. R. (2013). Contextos e padrões do uso indevido de benzodiazepínicos entre mulheres. Ciência \& Saúde Coletiva, 18(4), 1131-1140. doi.org/10.1590/S1413-81232013000400026.

Stuart, A. L., Mohebbi, M., Pasco, J. A., Quirk, S. E., Brennan-Olsen, S. L. Berk, M., \& Williams, L. J. (2017). Pattern of psychotropic medication use over two decades in Australian women. Aust N Z J Psychiatry, 51(12), 1212-1219. doi: 10.1177/0004867417704056.

Tesser, C. D. (2006). Social medicalization (I): the exaggerated success of modern 'epistemicide' in health. Interface - Comunic., Saúde, Educ., 10(19), 61-76. Doi: http://dx.doi.org/10.1590/S1414-32832006000100005.

Tong, A., Sainsbury, P., \& Craig, J. (2007). Consolidated criteria for reporting qualitative research (COREQ): a 32-itemchecklist for interviews and focus groups. International Journal for Quality in Health Care.19(6), 349-357.

van Geffen, E. C. G., Hermsen, J. H. C. M., Heerdink, E. R. Egberts, A. C. G., Verbeek-Heida, P. M, \& van Hulten, R. (2011). The decision to continue or discontinue treatment: Experiences and beliefs of users of selective serotonin-reuptake inhibitors in the initial months: A qualitative study. Research in Social and Administrative Pharmacy. 7, 134-150. Doi:10.1016/j. sapharm.2010.04.001.

van Manen, M. (1990). Researching lived experience: human science for an action sensitive pedagogy. New York, NY: State University of New York Press.

van Manen, M. (2014). Phenomenology of practice; meaning giving methods in phenomenology research and writing. California: Walnut Creek.

Verani, B. P., Souza, M. C., Parcias, S. R., Matias, T. S., \& Guimarães, A. C. A. (2016). Atividade física relacionada ao estresse no trabalho dos profissionais da área da saúde mental. Cinergis, 16(2), 115-119. doi.org/10.17058/cinergis. v16i2.6278.

Verbeek-Heida, P. M., \& Mathot, E. F. (2006). Better safe than sorry - why patients prefer to stop using selective serotonin reuptake inhibitor (SSRI) antidepressants but are afraid to do so: results of a qualitative study. Chronic Illness, 2, 133-142. doi.org/10.1177/17423953060020020801. 
Werremeyer, A., Skoy, E., \& Kelly, G. A. (2017). Use of Photovoice to Understand the Experience of Taking Psychotropic Medications. Qualitative Health Research. 27(13), 1959-1969. doi: 10.1177/1049732317693221.

\section{Resumos}

(O uso de medicamentos psicotrópicos e abordagens não farmacológicas na vida cotidiana: um estudo qualitativo da experiência vivida)

$O$ aumento do consumo de psicotrópicos tem sido observado no Brasil e em outros países ocidentais nas últimas décadas, por diferentes razões. O objetivo deste estudo foi compreender a vivência de indivíduos que utilizaram psicotrópicos para lidar com os problemas enfrentados no cotidiano. Um estudo qualitativo guiado pela fenomenologia hermenêtica foi realizado, agrupando-se o resultado em dois temas: experiência com o uso dos psicotrópicos e busca por abordagens não farmacológicas. Os psicotrópicos foram considerados necessários para recuperar um ponto de equilibrio quando se reconheceram os problemas enfrentados como tendo alto grau de dificuldade. Em alguns casos, os fármacos foram percebidos como insuficientes para solucionar o problema, levando ou não à busca de alternativas para lidar com as dificuldades.

Palavras-chave: Hermenêutica, pesquisa qualitativa, psicotrópicos, acontecimentos que mudam a vida

(L'usage de médicaments psychotropes et approches non pharmacologiques dans la vie quotidienne: une étude qualitative de l'experience vécue

Au cours des dernières décennies, on a observé l'augmentation de la consommation de médicaments psychotropes au Brésil et dans d'autres pays occidentaux pour différentes raisons. L'objectif de cette étude est de comprendre le vécu d'individus qui ont utilisé les psychotropes pour faire face aux problèmes de la vie quotidienne. Une étude qualitative, guidée par la phénoménologie herméneutique, a été réalisée. Le résultat a été divisé en deux thèmes: l'expérience découlant de l'usage de psychotropes et la recherche d'approches non pharmacologiques. Les psychotropes ont été considérés nécessaires pour récupérer un point d'équilibre lorsque les problèmes vécus ont été reconnus comme ayant un degré élevé de difficulté. Dans certains cas, les médicaments se sont révélés insuffisants pour résoudre le problème, entraînant ou pas la recherche d'alternatives pour faire face aux difficultés.

Mots clés: Herméneutique, recherche qualitative, psychotropes, événements qui changent la vie 


\section{SAÚDE MENTAL}

(El uso de medicamentos psicotrópicos y abordajes no farmacológicos en la vida cotidiana: um estudio cualitativo de la expericncia vivida)

En las últimas décadas y por diferentes razones, se ha observado en Brasil $y$ en otros países occidentales un aumento en el consumo de psicotrópicos. El objetivo de este estudio fue comprender la vivencia de individuos que utilizaron psicotrópicos para enfrentar los problemas del día a día. Se realizó un estudio cualitativo dirigido por la fenomenología hermenéutica. El resultado fue agrupado en dos temas: experiencia con el uso de los psicotrópicos y la búsqueda de enfoques no farmacológicos. Los psicotrópicos fueron considerados necesarios para recuperar un punto de equilibrio cuando los problemas enfrentados fueron reconocidos como problemas de alto grado de dificultad. En algunos casos, los fármacos fueron percibidos como insuficientes para solucionar el problema, llevando o no a la búsqueda de alternativas para enfrentar las dificultades.

Palabras clave: Hermenéutica, investigación cualitativa, psicotrópicos, acontecimentos que cambian la vida

(Die Anwendung von psychotropischen Medikamenten und nichtpharmakologische Ansätze im Alltag: eine qualitative Untersuchung des Erlebten erfahrung zusammenfassung)

In den letzten Jahrzehnten wird ein steigender Konsum von Psychotropika in Brasilien und in anderen westlichen Ländern festgestellt, der auf verschiedenen Faktoren beruht. Ziel dieser Untersuchung war es, die Lebensweise von Personen zu verstehen, die psychotropische Medikamente benutzen, um Alltagsprobleme zu meistern. Basierend auf der hermeneutischen Phänomenologie wurde dazu eine qualitative Untersuchung durchgeführt. Das Ergebnis wurde in zwei Themen eingeteilt: Erfahrungen mit der Benutzung von Psychotropika und die Suche nach nicht-pharmakologischen Ansätzen. Die Psychotropika wurden als notwendig betrachtet, um ein Gleichgewicht wiederherzustellen, wenn Probleme mit hohem Schwierigkeitsgrad zu meistern waren. In einigen Fällen wurden diese als unzureichend empfunden, was zur Suche nach Alternativen führte, um mit diesen Problemen umzugehen.

Schlüsselwörter: Hermeneutik, qualitative Untersuchung, Psychotropika, lebensverändernde Ereignisse 
Citação/Citation: Filardi, A. F. R., Mendonça, S. de A. M., Ramalho-de-Oliveira, D. (2019, dez.). The use of psychotropic medications and non-pharmacological approaches in everyday life: a qualitative study of the lived experience. Revista Latinoamericana de Psicopatologia Fundamental, 22(4), 859-883. http://dx.doi.org/10.1590/1415-4714.2019v22n4p859.11.

Editora/Editor: Profa. Dra. Erotildes Maria Leal

Submetido/Submitted: 04.04.2019 / 04.04.2019 Revisado/Revised: 10.09.2019 / 09.10.2019

Aceito/Accepted: $14.10 .2019 / 10.14 .2019$

Copyright: (C) 2009 Associação Universitária de Pesquisa em Psicopatologia Fundamental/ University Association for Research in Fundamental Psychopathology. Este é um artigo de livre acesso, que permite uso irrestrito, distribuição e reprodução em qualquer meio, desde que o autor e a fonte sejam citados / This is an open-access article, which permits unrestricted use, distribution, and reproduction in any medium, provided the original authors and sources are credited.

Financiamento/Funding: Este trabalho não recebeu apoio / This work received no funding.

Conflito de interesses/Conflict of interest: As autoras declaram que não há conflito de interesses. / The authors declare that there is no conflict of interest.

\section{Agnes Fonseca Ribeiro Filardi}

Master in Medicines and Pharmaceutical Assistance; PhD's Student in the Program in Medicines and Pharmaceutical Assistance, Faculty of Pharmacy, Federal University of Minas Gerais - UFMG (Belo Horizonte, MG, Br)

Av. Presidente Antônio Carlos, 6627 - Campus Pampulha

31270-901 Belo Horizonte, MG., Br

agnesfrf@gmail.com

https://orcid.org/:0000-0002-0685-2402 


\section{SAÚDE MENTAL}

Simone de Araúuo Medina Mendonça

PhD's in the Program in Medicines and Pharmaceutical Assistance, Faculty of Pharmacy, Federal University of Minas Gerais - UFMG (Belo Horizonte, MG, Br); Assistant Professor, Department of Pharmacy, Faculty of Pharmacy, Federal University of Minas Gerais (Belo Horizonte, MG, Br).

Av. Presidente Antônio Carlos, 6627 - Campus Pampulha

31270-901 Belo Horizonte, MG, Br.

simoneamm@gmail.com

https://orcid.org/:0000-0001-5792-0682

Djenane Ramalho-De-Oliveira

PhD - Social and Administrative Pharmacy; Professor and Coordinator for Pharmaceutical Care Research Centre (PCRC), Faculty of Pharmacy, Federal University of Minas Gerais UFMG (Belo Horizonte, MG, Br)

Av. Presidente Antônio Carlos, 6627 - Campus Pampulha

31270-901 Belo Horizonte, MG, Br.

djenane.oliveira@gmail.com

https://orcid.org/:0000-0002-5548-8184

This is an open-access article, which permits unrestricted use, distribution, and reproduction in any medium for non-commercial purposes provided the original authors and sources are credited.

Rev. Latinoam. Psicopat. Fund., São Paulo, 22(4), 859-883, dez. 2019 